\title{
Perencanaan Strategi Pemasaran Telur Ayam Untuk Meningkatkan Penjualan Pada Peternakan Budi Daya Alam Lestari Dengan Metode Marketing Mix Dan Topsis
}

\author{
Dewi Diniaty, ST. M.Ec. Dev ${ }^{1}$, Donni Setiawan Mahmud ${ }^{2}$ \\ ${ }^{1,2}$ Jurusan Teknik Industri Universitas Islam Negeri Sultan Syarif Kasim Riau \\ Jl. HR. Soebrantas No. 155 Simpang Baru, Panam, Pekanbaru, 28293 \\ Email : dewidiniaty@uin-suska.ac.id donni.mahmud@gmail.com
}

\begin{abstract}
ABSTRAK
Peternakan Budi Daya Alam Lestari merupakan usaha yang bergerak dibidang unggas yaitu telur ayam. Permasalahan yang dihadapi oleh Peternakan budi daya alam lestari ini yaitu menurunnya jumlah pendapatan dan terus meningkatnya biaya pokok dalam perawatan unggas. Tujuan penelitian ini adalah untuk mengetahui faktor-faktor yang mempengaruhi penjualan telur dengan metode Marketing Mix dan menentukan strategi terpilih dengan metode Technique for Order Preference by Similarity to Ideal Solution (TOPSIS). Berdasarkan metode Marketing Mix terdapat dua faktor yang mempengaruhi penjualan telur ayam yaitu dimensi promosi dan harga. Pemilihan strategi pemasaran dilakukan dengan Ratting Scale jawaban konsumen dan metode Technique for Order Preference by Similarity to Ideal Solution (TOPSIS). Hasil pengolahan data dari Ratting Scale dimensi yang menduduki skor tertinggi adalah dimensi promosi dengan nilai 0,78 , dan dimensi harga dengan nilai 0,22 . Strategi pemasaran terpilih dari hasil pengolahan metode TOPSIS adalah alternatif 1 yaitu dimensi promosi dengan nilai 0,78 dimana perusahaan berusaha untuk melakukan promosi yang cukup besar yaitu memberikan diskon harga pada biaya transportasi ongkos kirim untuk diantar ke konsumen yang tidak membeli secara langsung, memberikan potongan harga apabila membeli telur dalam jumlah besar, dengan tujuan dapat menarik pelanggan baru, mendorong pelanggan membeli lebih banyak dan dapat mengupayakan kerja sama yang cukup erat. juga meningkatkan promosi dapat diperoleh tidak hanya dari mulut ke mulut tetapi juga dari media social seperti facebook, instagram, whatsapp dan radio.
\end{abstract}

Kata Kunci: Strategi Pemasaran, Marketing Mix, TOPSIS 


\section{Pendahuluan}

Pada era globalisasi saat ini, segala sesuatu berjalan dan berkembang dengan pesat. Cepatnya laju pertumbuhan ekonomi pembangunan nasional tidak terlepas dari peran sektor pertanian. Berdasarkan Badan Statistik tahun 2016, sektor pertanian secara umum memiliki kontribusi tinggi dalam sumbangan terhadap Produk Domestik Bruto (PDB) Nasional. Sektor pertanian memiliki beberapa sub-sektor, salah satunya peternakan merupakan sub-sektor terbesar ketiga yang berkontribusi dalam membentuk sektor pertanian pada PDB Nasional. Salah satu jenis usaha pada sub-sektor peternakan adalah Ayam Ras Petelur yang bertujuan untuk memenuhi permintaan telur ayam yang semakin meningkat dari tahun ke tahun. Produksi ayam ras petelur kota Pekanbaru tahun 2014-2016.

Produksi ayam petelur di Kota Pekanbaru pada 2014 adalah sebesar 27\%, kemudian pada tahun 2015 produksi telur terus bertambah sebanyak 29\% sampai dengan tahun 2016 produksi telur sebanyak $36 \%$. Dengan meningkatnya produksi telur ayam tentu saja diimbangi dengan terus meningkatnya permintaan (Demand) terhadap telur ayam, dimana dapat kita lihat dari Tabel 1.1 berikut.

Tabel 1.1 Permintaan Telur Ayam per Minggu Tahun 2013-2016

\begin{tabular}{|c|c|}
\hline Tahun & Permintaan (Demand) $/ \mathrm{kg}$ \\
\hline 2013 & 0,169 \\
\hline 2014 & 0,171 \\
\hline 2015 & 1,940 \\
\hline 2016 & 2,065 \\
\hline
\end{tabular}

(Sumber: Badan Pusat Statistik Pekanbaru)

Hal ini membuktikan bahwa konsumsi masyarakat terhadap telur terus meningkat. Selain itu telur juga menjadi bahan baku industri makanan. Usaha peternakan ayam petelur dapat berkembang dengan pesat karena usaha ini dapat dilakukan pada lahan yang tidak terlalu luas. Oleh karena itu keberhasilan usaha peternakan selain tergantung dari sisi peternak dalam hal pengelolaan juga pada besar kecilnya biaya produksi yang sangat tergantung pada satu hal, yaitu pemasaran produk, sebab pemasaran merupakan faktor yang sangat penting dalam menentukan keberhasilan suatu usaha.
Usaha peternakan ayam petelur Budi Daya Alam Lestari merupakan salah satu usaha penghasil telur ayam yang ada di daerah kota Pekanbaru, tepatnya berada di Kecamatan Tenayan Raya, Kulim. Usaha telur ayam di peternakan Budi Daya Alam Lestari yang berdiri sejak tahun 2015, Peternakan Budi Daya Alam Lestari memiliki dua orang pekerja serta memiliki ternak ayam sebanyak 1000 ekor ayam ras petelur, yang mampu menghasilkan sekitar $600-800$ butir telur per harinya

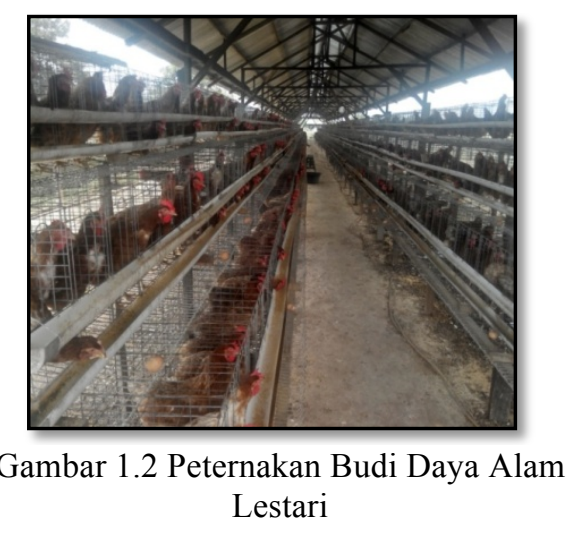

Gambar 1.2 merupakan Usaha telur ayam di peternakan Budi Daya Alam Lestari. Pada usaha ini pengelola ternak ayam telur melakukan pemasaran produknya dengan cara yang sederhana, yaitu melalui mulut ke mulut menawarkan produk telur nya dan ada pula strategi pemasaran lainnya yang digunakan adalah melalui media sosial seperti aplikasi pesan BBM. Dengan strategi pemasaran yang kurang luas ini yang menjadi salah satu kendala mengapa penjualan produk dari usaha telur ayam di peternakan Budi Daya Alam Lestari ini menjadi berkurang dari waktu ke waktu nya, sehingga telur yang tersisah karena tidak terjual habis bertambah dan tersimpan dalam ruang penyimpanan telur. Masalah lain yaitu adanya telur pecah karena penyimpanan yang kurang diperhatikan maupun karena kelalaian pekerja. Dari uraian ini terlihat bahwa permasalahan yang dihadapai oleh usaha peternak ayam ini adalah menurunnya jumlah pendapatan yang dihasilkan dari usaha ternak ayam petelur di peternakan Budi Daya Alam Lestari. 


\section{Pendapatan dan Biaya Pokok}

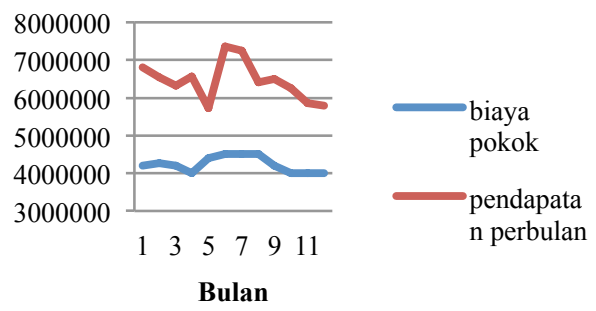

Gambar 1.3 Pendapatan dan Biaya Pokok

Pada Gambar 1.3 dapat dilihat bahwa terjadinya penurunan pendapatan pada usaha ternak ayam ras petelur. Berdasarkan hasil pengamatan yang dilakukan, penurunan ini terjadi karena belum pastinya jumlah saluran atau distributor untuk pemasaran usaha ternak ayam petelur tersebut dan juga kebutuhan pokok yang didalamnya mencakup gaji pekerja, makan ternak dan pembelian papan telur. Menurunnya pendapatan juga disebabkan oleh jumlah telur pada ternak ayam tersebut banyak yang pecah, hal ini dapat dilihat pada Tabel 1.2 sebagai berikut.

Berdasarkan hasil penyebaran kuesioner yang dilakukan, dapat di lihat bahwa konsumen yang memberikan respon positif terhadap produk sebanyak $44 \%$ sedangkan produsen yang memberikan respon negatif sebanyak 56\%. Dari hasil kuesioner pendahuluan dapat dilihat bahwa strategi pemasaran yang digunakan saat ini oleh peternakan Budi Daya Alam Lestari belum optimal. Hal yang mempengaruhi seperti harga yang kurang kompetitif, promosi yang tidak maksimal, lokasi yang kurang strategis dan pelayanan yang minim merupakan permasalahan yang terjadi pada peternakan Budi Daya Alam Lestari.

Berdasarkan permasalahan yang terjadi pada peternakan Budi Daya Alam Lestari, maka peternakan Budi Daya Alam Lestari harus mampu merumuskan strategi pemasaran yang lebih baik. Dalam memilih strategi pemasaran yang kompetitif, dibutuhkan berbagai penelitian dari beberapa faktor.

Penelitian ini dilakukan untuk membantu usaha telur ayam di perkebunan Budi Daya Alam Lestari dalam merencanakan strategi pemasaran produk yang lebih baik lagi dengan menggunakan metode Marketing Mix agar dapat meningkatkan penjualan. Metode Marketing Mix merupakan metode yang cocok digunakan untuk mengetahui faktor-faktor apa saja yang berpengaruh terhadap usaha telur ayam di perkebunan Budi Daya Alam Lestari. Adapun metode Marketing Mix (7P) dan Topsis (technique for order performance by similarity to deal solution) merupakan teknik atau cara yang digunakan dalam mengambil suatu keputusan, Topsis menggunakan prinsip bahwa alternatif yang terpilih harus mempunyai jarak terdekat dari solusi ideal positif dan jarak terpanjang (terjauh) dari solusi ideal. Pentingnya pemilihan strategi yang tepat tidak lepas dari proses pengambilan keputusan didalam perusahaan (Internal) khususnya peternakan Budi Daya Alam Lestari. Karena hal ini berkaitan dengan tindakan yang akan dilakukan, apalagi masalah tersebut terkait dengan kemajuan suatu perusahaan yang melibatkan banyak pihak, sehingga kesalahan yang timbul berdampak pada mundurnya perusahaan tersebut. Maka berdasarkan latar belakang diatas, penelitian ini mengambil judul yaitu " Perencanaan Strategi Pemasaran Telur Ayam Pada Budi Daya Alam Lestari Untuk Meningkatkan Penjualan Dengan Pendekatan Marketing Mix Dan Topsis".

\section{Metode Penelitian}

Tahapan penelitian dipaparkan pada flowchart dibawah ini: 


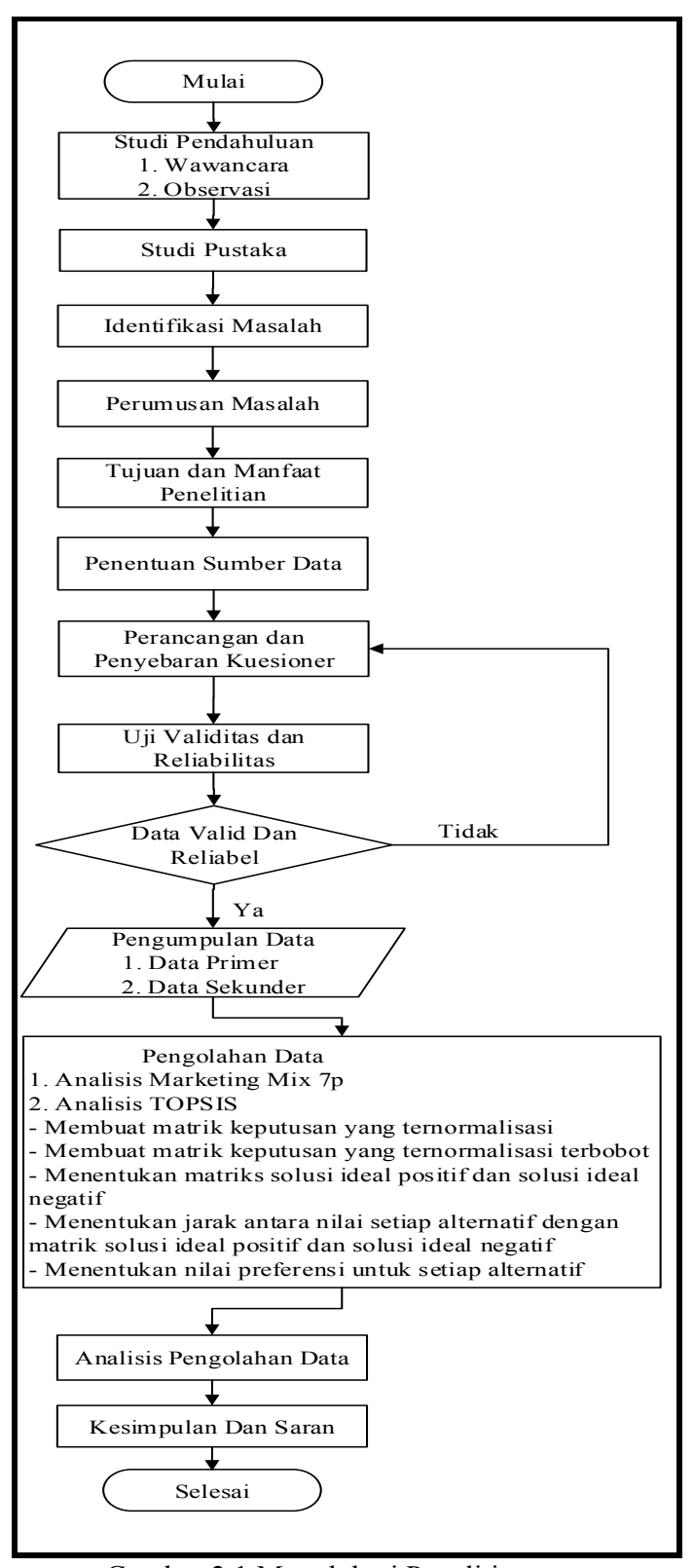

Gambar 2.1 Metodologi Penelitian

\section{Hasil dan Pembahasan}

\subsection{Metode Technique For Order Preference by Similarity to Ideal Solution (TOPSIS)}

Metode TOPSIS didasarkan pada Bencmarking dari keunggulan pesaing. alternatif terpilih yang terbaik tidak hanya memiliki jarak terpendek dari solusi ideal positif tetapi juga memiliki jarak terpanjang dari solusi ideal negatif. Nilai bobot dari setiap kriteria ditentukan dengan skala angka 1-5 berdasarkan tingkat kepentingan kriteria yang ada. Sedangkan untuk alternatifnya didapatkan dari Keunggulan Pesaing adalah sebagai berikut:

1. Promosi

Melakukan promosi yang cukup besar sehingga informasi dapat diperoleh tidak hanya dari mulut kemulut tetapi juga dari media massa dan radio.

2. Harga

Perusahaan selalu mengikuti harga pasar yang berlaku sehingga pelanggan tidak mudah untuk beralih ke produsen lain dan memberikan potongan harga apabila produsen membeli dalam jumlah besar.

\subsection{Membuat matriks keputusan yang ternormalisasi}

Berdasarkan data pada Tabel 4.12 maka, dapat dikontruksi rata-rata matriks keputusan ternomalisasi yang dapat dilihat pada Tabel 3.1.

Tabel 3.1 Hasil Perhitungan Rata-rata Matriks Penilaian Kriteria

\begin{tabular}{|c|c|c|c|c|c|c|c|c|}
\hline & C1 & C2 & C3 & C4 & C5 & C6 & C7 & C8 \\
\hline A1 & 4,20 & 3,90 & 3,90 & 3,80 & 4,30 & 4,00 & 3,33 & 4,33 \\
\hline $\mathbf{A 2}$ & 3,20 & 3,50 & 3,90 & 3,80 & 3,50 & 4,33 & 3,67 & 4,00 \\
\hline
\end{tabular}

(Sumber : Pengolahan Data, 2017)

Langkah selanjutnya adalah menghitung matriks yang ternormalisir menggunakan rumus :

$$
\begin{aligned}
& \mathrm{R}_{\mathrm{ij}}=\frac{\mathrm{x}_{\mathrm{ij}}}{\sqrt{\sum_{\mathrm{i}=1}^{\mathrm{m}} \mathrm{x}_{\mathrm{ij}}^{2}}} \text { Dimana }: i=1,2 \ldots . ., \\
& \mathrm{m} ; \text { dan } \mathrm{j}=1,2, \ldots ., \mathrm{n}
\end{aligned}
$$

a. Untuk C1 (Kemampuan Manajemen)

$$
\begin{aligned}
\left|\mathrm{x}_{1}\right| & =\sqrt{(2,67)^{2}+(3,67)^{2}} \\
& =\sqrt{7,11+13,44} \\
& =4,53 \\
\mathrm{R}_{1.1} & =\frac{2,67}{4,53}=0,59 \\
\mathrm{R}_{1.2} & =\frac{3,67}{4,53}=0,81
\end{aligned}
$$

Rekapitulasi perhitungan dapat dilihat pada Tabel 3.2 sebagai berikut: 
Tabel 3.2 Hasil Perhitungan Matriks Ternormalisir

\begin{tabular}{|c|c|c|c|c|c|c|c|c|}
\hline & C1 & C2 & C3 & C4 & C5 & C6 & C7 & C8 \\
\hline A1 & 0.59 & 0.68 & 0.74 & 0.68 & 0.67 & 0.68 & 0.67 & 0.73 \\
\hline A2 & 0.81 & 0.74 & 0.68 & 0.74 & 0.74 & 0.73 & 0.74 & 0.68 \\
\hline
\end{tabular}

(Sumber : Pengolahan Data, 2017)

\subsection{Menghitung Matriks yang Ternormalisasi Terbobot (Y) \\ Langkah selanjutnya adalah} menghitung matriks ternormalisir terbobot. Bobot preferensi (W) setiap kriteria ditentukan oleh perusahaan usaha kecil menengah dari Peternakan Budi Daya Alam Lestari. sebagai berikut:

Tabel 3.3 Bobot Preferensi dari Peternakan Budi Daya Alam Lestari

\begin{tabular}{|c|c|l|}
\hline No & Kode & \multicolumn{1}{|c|}{ Kriteria } \\
\hline 1 & C1 & Kemampuan manajemen \\
\hline 2 & C2 & $\begin{array}{l}\text { Ketepatan waktu } \\
\text { pengiriman }\end{array}$ \\
\hline 3 & C3 & $\begin{array}{l}\text { Membuka sarana } \\
\text { pemasaran (gerai, toko) }\end{array}$ \\
\hline 4 & C4 & $\begin{array}{l}\text { Meningkatkan promosi } \\
\text { (membuat brosur, iklan } \\
\text { baris, radio, dan } \\
\text { memasarkan kepada } \\
\text { konsumen potensial) }\end{array}$ \\
\hline 5 & C5 & $\begin{array}{l}\text { Memberikan layanan } \\
\text { pemesanan melalui media } \\
\text { sosial }\end{array}$ \\
\hline 6 & C6 & Harga penawaran \\
\hline 7 & C7 & Biaya transportasi \\
\hline 8 & C8 & Potongan harga \\
\hline
\end{tabular}

(Sumber : Pengolahan Data, 2017)

Untuk menghitung matriks yang ternormalisir terbobot menggunakan rumus berikut :

$$
\boldsymbol{y}_{i j}=\boldsymbol{w}_{i} \boldsymbol{r}_{i j} ; \text { dengan } \mathrm{I}=1,2, \ldots, \mathrm{m} ; \text { dan } \mathrm{j}=
$$

A1

$$
\mathrm{y}_{11}=(5)(0,59)=\quad \mathrm{y}_{15}=(4)(0,67)=2,6 \text { c }
$$

$$
2,94
$$$$
\mathrm{y}_{12}=(4)(0,68)=2, \quad \mathrm{y}_{16}=(3)(0,68)=2,0
$$$$
70
$$$$
\mathrm{y}_{13}=(3)(0,74)=2,2: \mathrm{y}_{17}=(3)(0,67)=2,0 \text { : }
$$$$
y_{14}=(3)(0,68)=2,0 . \quad y_{18}=(5)(0,73)=3,6
$$

Rekapitulasi matriks ternomalisir terbobot (Y) pada Tabel 4.20 sebagai berikut:
Tabel 3.4 Matriks Ternormalisir Terbobot (Y)

\begin{tabular}{|c|c|c|c|c|c|c|c|c|}
\hline & C1 & C2 & C3 & C4 & C5 & C6 & C7 & C8 \\
\hline A1 & 2.94 & 2.70 & 2.21 & 2.03 & 2.69 & 2.03 & 2.02 & 3.67 \\
\hline A2 & 4.04 & 2.95 & 2.03 & 2.21 & 2.96 & 2.20 & 2.22 & 3.39 \\
\hline
\end{tabular}

(Sumber : Pengolahan Data, 2017)

\subsection{Menentukan Solusi Ideal Positif $\left(A^{+}\right)$dan Solusi Ideal Negatif $\left(A^{-}\right)$}

Menentukan solusi ideal positif $\left(\mathrm{A}^{+}\right)$dan solusi Ideal negatif $\left(\mathrm{A}^{-}\right)$dengan menggunakan rumus berikut :

\begin{tabular}{|c|c|c|c|c|c|c|}
\hline $\mathbf{Y}_{\mathbf{i}}$ & \multicolumn{4}{|c|}{ Solusi Ideal } & Min & Max \\
\hline $\mathrm{C} 1$ & 2,94 & 4,04 & 4,04 & 2,94 & 2,94 & 4,04 \\
\hline $\mathrm{C} 2$ & 2,70 & 2,95 & 2,95 & 2,70 & 2,70 & 2,95 \\
\hline C3 & 2,21 & 2,03 & 2,21 & 2,03 & 2,21 & 2,03 \\
\hline $\mathrm{C} 4$ & 2,03 & 2,21 & 2,21 & 2,03 & 2,03 & 2,21 \\
\hline $\mathrm{C} 5$ & 2,69 & 2,96 & 2,96 & 2,69 & 2,69 & 2,96 \\
\hline C6 & 2,03 & 2,20 & 2,20 & 2,03 & 2,03 & 2,20 \\
\hline $\mathrm{C} 7$ & 2,02 & 2,22 & 2,22 & 2,02 & 2,02 & 2,22 \\
\hline $\mathrm{C} 8$ & 3,67 & 3,39 & 3,67 & 3,39 & 3,67 & 3,39 \\
\hline
\end{tabular}

$$
\mathrm{A}^{+}=\max \left(\mathrm{y}_{1}^{+}, \mathrm{y}_{2}^{+}, \ldots, \mathrm{y}_{\mathrm{n}}^{+}\right)
$$

Tabel 3.5 Solusi Ideal Positif (A+) dan Matriks Ideal Negatif (A-)

(Sumber : Pengolahan Data, 2017)

Sehingga didapat Matriks Solusi Ideal Positif $(\mathrm{A}+)$ dan Matriks Ideal Negatif (A-) pada Tabel 3.6 sebagai berikut :

Tabel 3.6 Solusi Ideal Positif $\left(A^{+}\right)$dan Solusi Ideal Negatif $\left(A^{-}\right)$

\begin{tabular}{|c|c|c|c|c|c|c|c|c|}
\hline $\mathbf{A}+$ & 4,04 & 2,95 & 2,21 & 2,21 & 2,96 & 2,2 & 2,22 & 3,67 \\
\hline $\mathbf{A}-$ & 2,94 & 2,7 & 2,03 & 2,03 & 2,69 & 2,03 & 2,02 & 3,39 \\
\hline
\end{tabular}

(Sumber : Pengolahan Data, 2017)

\subsection{Menghitung Jarak Solusi Ideal Positif $\left(D^{+}\right)$dan Solusi Ideal Negatif $\left(D^{-}\right)$.}

Tahap selanjutnya adalah menghitung jarak solusi ideal positif dan solusi ideal negatif menggunakan rumus :

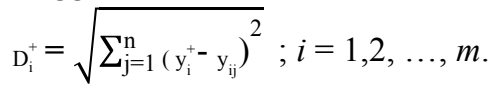

$(4,04-2,94)^{2}+(2,95-2,70)^{2}+(2,21-2,21)^{2}$

$D_{1}^{+}=+(2,21-2,03)^{2}+(2,96-2,69)^{2}+(2,20-2,03)^{2}$ $=1,20$

Rekapitulasi jarak solusi ideal positif dan solusi ideal negatifyang dapat dilihat pada Tabel berikut: 
Tabel 3.7 sebagai berikut.

\begin{tabular}{|c|c|}
\hline \multicolumn{2}{|c|}{$\mathbf{D}_{\mathbf{i}}^{+}$} \\
\hline $\mathrm{D}_{1}^{+}$ & 1,20 \\
\hline $\mathrm{D}_{2}^{+}$ & 0,34 \\
\hline \multicolumn{2}{|c|}{$\left(\mathbf{D}_{\mathbf{i}}^{-}\right.$} \\
\hline $\mathrm{D}_{1}^{-}$ & 0,34 \\
\hline $\mathrm{D}_{2}^{-}$ & 1,20 \\
\hline
\end{tabular}

(Sumber: Pengolahan Data, 2017)

\subsection{Menghitung Nilai Preferensi untuk setiap alternatif}

Menghitung nilai preferensi setiap alternatif menggunakan Rumus:

$\mathrm{V}_{\mathrm{i}}=\frac{\mathrm{D}_{\mathrm{i}}^{-}}{\mathrm{D}_{\mathrm{i}}^{-}+\mathrm{D}_{\mathrm{i}}^{+}}$, dimana $i=1,2,3, \ldots m$.

$\mathrm{V}_{1}=\frac{0,34}{0,34+1,20}=0,22$

Sehingga, dihasilkan nilai preferensi setiap alternatif yang dapat dilihat pada Tabel 3.9 sebagai berikut :

Tabel 3.9 Nilai Preferensi Setiap Alternatif

\begin{tabular}{|c|c|}
\hline \multicolumn{2}{|c|}{$\mathbf{V i}$} \\
\hline $\mathrm{V}_{1}$ & 0,22 \\
\hline $\mathrm{V}_{2}$ & 0,78 \\
\hline
\end{tabular}

(Sumber: Pengolahan Data, 2017)

Dari nilai hasil perhitungan diatas, dapat dilihat bahwa nilai $\mathrm{V}$ yang memiliki nilai terbesar yaitu $\mathrm{V}_{1}$. Urutan Rangking : $\mathrm{V}_{2}>\mathrm{V}_{1}$.

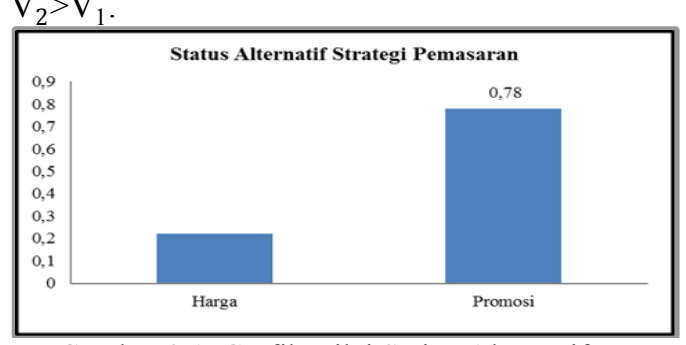

Gambar 3.1 Grafik Nilai Setiap Alternatif

Berdasarkan hasil preferensi pada Gambar 3.1 maka, dapat diketahui urutan rangking alternatif dapat dilihat pada Tabel 3.10 sebagai berikut :

Tabel 3.10 Urutan Rangking Alternatif

\begin{tabular}{|c|c|c|}
\hline Rangking & Alternatif & Total Nilai \\
\hline 1 & $\mathrm{~A}_{1}$ & 0,78 \\
\hline 2 & $\mathrm{~A}_{3}$ & 0,22 \\
\hline
\end{tabular}

(Sumber: Pengolahan Data, 2017)

\subsection{Analisis Uji $F$}

Dalam penelitian uji $\mathrm{F}$ dilakukan untuk mengetahui apakah setiap variabel bebas 7P mempunyai pengaruh yang signifikan terhadap minat beli konsumen yaitu secara bersama-sama. Hasil uji F dilakukan dengan cara membandingkan antara nili $\mathrm{F}$ hitung $>\mathrm{F}$ tabel maka $\mathrm{H}_{0}$ ditolak $\mathrm{H}_{1}$ diterima, hal ini menunjukkan bahwa secara bersama-sama variabel bebas $7 \mathrm{p}$ mempengaruhui minat beli konsumen.

Dari hasil pengolahan diperoleh bahwa nilai $\mathrm{F}$ hitung sebesar 5,864 dan nilai $\mathrm{F}$ tabel sebesar 2,19 ini berarti, nilai $\mathrm{F}$ hitung lebih besar sehingga $\mathrm{H}_{1}$ diterima, Hal ini menandakan bahwa ada pengaruh secara signifikan antara variabel 7P secara bersama-sama terhadap minat beli konsumen.

\subsection{Analisis Uji T}

Uji t digunakan untuk menunjukkan pengaruh secara parsial dari masing-masing variabel 7P, hasil uji $\mathrm{t}$ sesuai dengan perhitungan SPSS adalah sebagai berikut.

\section{Variabel Produk terhadap minat beli} konsumen

Dari pengolahan data yang telah dilakukan sebelumnya diperoleh nilai $t$ hitung sebesar 1,927 dengan tingkat kepercayaan $95 \% \quad(\alpha=5 \%)$, derajat kebebasan sebesar 99 dan nilai $t$ tabel sebesar sebesar 1,984. nilai t hitung $<\mathrm{t}$ tabel $(1,927<1,984)$ maka $\mathrm{H}_{0}$ diterima, ini berarti secara parsial produk berpengaruh positif dan tidak signifikan terhadap minat beli konsumen.

\section{Variabel Harga terhadap minat beli konsumen}

Dari pengolahan data yang telah dilakukan sebelumnya diperoleh nilai $t$ hitung sebesar 2,216 dengan tingkat kepercayaan $95 \% \quad(\alpha=5 \%)$, derajat kebebasan sebesar 99 dan nilai $t$ tabel sebesar sebesar 1,984. nilai t hitung $>\mathrm{t}$ tabel $(2,216>1,984)$ maka $\mathrm{H}_{0}$ ditolak, ini berarti secara parsial harga berpengaruh positif dan signifikan terhadap minat beli konsumen dan menunjukkan jika penambahan satu variabel pada harga akan meningkatkan minat beli konsumen serta penjualan sebesar 0,237 atau 23,7\%.

3. Variabel Promosi terhadap minat beli konsumen

Dari pengolahan data yang telah dilakukan sebelumnya diperoleh nilai $t$ hitung sebesar 2,561 dengan tingkat kepercayaan 95\% $(\alpha=5 \%)$, derajat kebebasan sebesar 99 dan nilai t tabel 
sebesar sebesar 1,984 . nilai $\mathrm{t}$ hitung $>\mathrm{t}$ tabel $(2,561>1,984)$ maka $\mathrm{H}_{0}$ ditolak, ini berarti secara parsial promosi berpengaruh positif dan signifikan terhadap minat beli konsumen dan menunjukkan jika penambahan satu variabel pada promosi akan meningkatkan minat beli konsumen serta penjualan sebesar 0,267 atau $26,7 \%$ pada promosi.

\section{Variabel Lokasi terhadap minat beli} konsumen

Dari pengolahan data yang telah dilakukan sebelumnya diperoleh nilai $t$ hitung sebesar -0,812 dengan tingkat kepercayaan $95 \%(\alpha=5 \%)$, derajat kebebasan sebesar 99 dan nilai t tabel sebesar sebesar 1,984. nilai $\mathrm{t}$ hitung $<\mathrm{t}$ tabel $(-0,210<1,984)$ maka $\mathrm{H}_{0}$ diterima, ini berarti secara parsial lokasi berpengaruh positif dan tidak signifikan terhadap minat beli konsumen, pada lokasi berpengaruh positif tetapi tidak terlalu signifikan karena hanya akan memberi peningkatan 0,023 atau 2,3\% pada lokasi.

\section{Variabel Pelayanan terhadap minat} beli konsumen

Dari pengolahan data yang telah dilakukan sebelumnya diperoleh nilai $t$ hitung sebesar $-0,901$ dengan tingkat kepercayaan $95 \% \quad(\alpha=5 \%)$, derajat kebebasan sebesar 99 dan nilai $t$ tabel sebesar sebesar 1,984. nilai $\mathrm{t}$ hitung $<\mathrm{t}$ tabel $(-0,901<1,67)$ maka $_{0}$ diterima, ini berarti secara parsial pelayanan berpengaruh positif dan tidak signifikan terhadap minat beli konsumen, pada pelayanan berpengaruh positif tetapi tidak signifikan karena hanya akan memberi peningkatan 0,094 atau 9,4\% pada pelayanan.

\section{Variabel Bukti Fisik terhadap minat beli konsumen}

Dari pengolahan data yang telah dilakukan sebelumnya diperoleh nilai $t$ hitung sebesar 0,120 dengan tingkat kepercayaan $95 \%(\alpha=5 \%)$, derajat kebebasan sebesar 99 dan nilai $t$ tabel sebesar sebesar 1,984 . nilai t hitung $<\mathrm{t}$ tabel $(0,120<1,984)$ maka $H_{0}$ diterima, ini berarti secara parsial bukti fisik berpengaruh positif dan tidak signifikan terhadap minat beli konsumen, pada bukti fisik berpengaruh positif tetapi tidak signifikan karena hanya akan memberi peningkatan 0,019 atau 1,9\%.

7. Variabel Proses terhadap minat beli konsumen
Dari pengolahan data yang telah dilakukan sebelumnya diperoleh nilai $t$ hitung sebesar 1,002 dengan tingkat kepercayaan 95\% $(\alpha=5 \%)$, derajat kebebasan sebesar 99 dan nilai t tabel sebesar sebesar 1,984. nilai t hitung $<\mathrm{t}$ tabel $(1,002<1,67)$ maka $\mathrm{H}_{0}$ diterima, ini berarti secara parsial proses berpengaruh positif dan dan tidak signifikan terhadap minat karena tidak terlalu signifikan karena jika terjadi kenaikan pada variabel proses hanya akan memberi peningkatan sebesar 0,105 atau $10,5 \%$.

\subsection{Analisa Uji Determinasi $\left(R^{2}\right)$}

Identifikasi determinan $\left(\mathrm{R}^{2}\right)$ digunakan untuk melihat seberapa besar pengaruh variabel (X) bebas yaitu variabel produk, harga, promosi, lokasi, pelayanan, bukti fisik dan proses secara parsial berpengaruh positif dan signifikan terhadap variabel terikat $(\mathrm{Y})$ yaitu variabel minat beli konsumen dimana $0<\mathrm{R}^{2}<1$. Dari model persamaan $\mathrm{D}=\mathrm{R}^{2}$ akan dapat dihitung $\mathrm{R}^{2}$ atau coefficient of determination yang menunjukkan persentase dari variasi variabel keputusan yang mampu dijelaskan oleh model, hasil uji $\mathrm{R}^{2}$ sesuai dengan perhitungan SPSS. Dari hasil pengolahan diperoleh nilai $\mathrm{R}$ sebesar 0,555 atau $55,5 \%$. Nilai $R$ yang mendekasti 1 ini berarti bahwa terjadi hubungan yang semakin erat antara 7P (produk, harga, promosi, lokasi, pelayanan, bukti fisik, proses).

$R$ square sebesar 0,309 berarti $30,9 \%$. Hal ini menunjukkan bahwa persentase sumbangan pengaruh variabel independen (b1, b2, b3, b4, b5, b6, b7) terhadap variabel dependen (minat beli konsumen), atau variasi variabel independen yang digunakan dalam model (b1, b2, b3, b4, b5, b6, b7) mampu menjelaskan sebesar $30,9 \%$ variasi dependen (kepercayaan konsumen). Sedangkan sisanya $60,6 \%$ dipengaruhi atau dijelaskan oleh variabel lain yang tidak dimasukkan dalam model penelitian ini.

\subsection{Analisis Faktor-faktor Bauran Pemasaran yang Mempengaruhi Penjualan Telur \\ Berdasarkan hasil perhitungan} faktor-faktor yang mempengaruhi tingkat pendapatan pada Peternakan Budi Daya 
Alam Lestari, diketahui dua faktor yang berpengaruh adalah sebagai berikut:

\section{Faktor Promosi}

Faktor promosi mendapatkan nilai variabel tertinggi yaitu menaikkan jumlah penjualan sebesar 0,70 atau $70 \%$ dari faktor yang lainnya. Hal ini disebabkan karena perusahaan Budi Daya Alam Lestari belum melakukan promosi yang cukup berarti. Informasi hanya diperoleh dari mulut ke mulut melalui para pelanggan ke calon pelanggan lainnya. Tidak ada promosi khusus yang digunakan seperti melalui media massa atau radio. Hal ini juga menyebabkan kerugian karena kapasitas produksi telur yang memadai tidak diiringi dengan promosi yang berarti, sehingga membuat cakupan pemasarannya kecil. Untuk itu perusahaan harus melakukan promosi yang cukup besar sehingga informasi dapat diperoleh tidak hanya dari mulut ke mulut tetapi juga dari media massa dan radio dan memberikan potongan harga apabila konsumen membeli dalam jumlah yang banyak.

\section{Dimensi Harga}

Dimensi harga menduduki nilai variabel kedua dengan nilai keberhasilan penjualan yaitu sebesar 0,22 atau $22 \%$. Hal ini dikarenakan perusahaan belum mengikuti harga pasar yang berlaku di pasaran sehingga konsumen atau pelanggan akan mudah beralih ke produsen lain, harga telur ayam saat ini dijual seharga $\mathrm{Rp} 32.000$,dan perusahaan tidak memberi potongan harga kepada konsumen apabila membeli telur ayam dalam jumlah besar. Untuk itu perusahaan harus mengikuti harga pasar yang berlaku sehingga pelanggan tidak mudah untuk beralih ke produsen lain dan memberikan potongan harga apabila produsen membeli dalam jumlah besar.

Hasil nilai analisis faktor-faktor berdasarkan jawaban responden, 2 faktor tertinggi akan menjadi strategi pendukung dalam penerapan strategi pemasaran pada perhitungan TOPSIS.

\subsection{Metode Technique For Order Preference by Similarity to Ideal Solution (TOPSIS)}

Hasil perhitungan dari metode TOPSIS berdasarkan penilaian responden ahli dan preferensi perusahaan adalah keputusan akhir untuk pemilihan strategi pemasaran. Berikut ini adalah urutan nilai dari setiap alternatif strategi pemasaran berdasarkan hasil perhitungan TOPSIS adalah sebagai berikut:

\section{Strategi Promosi}

Hasil dari perhitungan TOPSIS pada bab sebelumnya, strategi promosi berada ditingkat pertama dengan nilai sebesar 0,70. Menunjukkan bahwa strategi ini cocok dengan semua dimensi penilaian konsumen, jika dikaitkan dengan penilaian konsumen pada variabel yang berpengaruh, dimana variabel promosi menduduki posisi pertama dengan tingkat kenaikan penjualan sebesar $70 \%$. Tujuan strategi ini adalah mengajak perusahaan untuk meningkatkan penjualan dengan melakukan promosi yang cukup besar yaitu memberikan diskon harga pada biaya transportasi ongkos kirim untuk diantar ke produsen yang tidak membeli secara langsung, memberikan potongan harga apabila membeli telur dalam jumlah besar, dengan tujuan dapat menarik pelanggan baru, mendorong pelanggan membeli lebih banyak dan dapat mengupayakan kerja sama yang cukup erat. juga meningkatkan promosi dapat diperoleh tidak hanya dari mulut ke mulut tetapi juga dari media social seperti facebook, instagram, whatsapp dan radio.

\section{Strategi Harga}

Strategi produk berada ditingkat kedua berdasarkan perhitungan TOPSIS yaitu dengan nilai sebesar 0,22 . Strategi ini membawa perusahaan keluar dari krisis dengan cara perusahaan harus mengikuti harga pasar yang berlaku sehingga pelanggan tidak mudah untuk beralih ke produsen lain dan memberikan potongan harga apabila produsen membeli telur dalam jumlah besar.

\section{Kesimpulan}

Berdasarkan hasil penelitian yang telah dilakukan di Peternakan Budi Daya Alam Lestari, maka dapat dibuat kesimpulan berdasarkan tujuan yang telah ditetapkan. Kesimpulan yang dapat diambil dari penelitian ini adalah sebagai berikut:

1. Faktor-faktor yang mempengaruhi usaha telur ayam pada peternakan Budi Daya Alam Lestari ada dua yaitu faktor promosi, faktor harga. Pada faktor promosi Perusahaan Budi Daya Alam 
Lestari belum melakukan promosi yang cukup besar. Informasi hanya diperoleh dari mulut ke mulut melalui para pelanggan ke calon pelanggan lainnya. Tidak ada promosi khusus yang digunakan seperti melalui media massa atau radio. Faktor harga dimana perusahaan belum mengikuti harga pasar yang berlaku sehingga konsumen atau pelanggan akan mudah beralih ke produsen lain.

2. Rancangan ulang strategi pemasaran terpilih yaitu strategi Promosi mendapat nilai tertinggi dengan nilai 0,70 , dimana tujuan strategi ini adalah mengajak perusahaan untuk meningkatkan penjualan dengan melakukan promosi yang cukup besar yaitu memberikan diskon harga pada biaya transportasi ongkos kirim untuk diantar ke produsen yang tidak membeli secara langsung, memberikan potongan harga apabila membeli telur dalam jumlah besar, dengan tujuan dapat menarik pelanggan baru, mendorong pelanggan membeli lebih banyak dan dapat mengupayakan kerja sama yang cukup erat. juga meningkatkan promosi dapat diperoleh tidak hanya dari mulut ke mulut tetapi juga dari media social seperti facebook, instagram, whatsapp dan radio.

\section{Daftar Pustaka}

[1] Ansofino. 2016. "Integrasi

Perekonomian Kabupaten dan Kota di Sumatera Barat Menuju

Integrasi Pasar Untuk Menghadapi

Masyarakat Ekonomi ASEAN

2015". Jurnal IPTEKS Terapan.

STKIP PGRI. Sumatera Barat.

[2] Arikunto, S. 2006. Prosedur Penelitian Suatu Pendekatan Praktek. Penertbit Rineka Cipta. Jakarta.

[3] Arvianto. A. 2014. "Pemilihan Strategi Pemasaran Pada PT. Nyonya Meneer dengan Menggunakan Pendekatan Metode ANP dan TOPSIS" Jurnal J@ti Undip, Volume 9, No.1. Januari.. Available

[4] Azmi, M. 2013. "Sistem Pengambilan Keputusan Untuk Memilih Usaha Waralaba Makanan Menggunakan
Metode Topsis". Jurnal Elektron Volume 5 Nomor 2 Desember, 2013. Politeknik Negeri Padang.

[5] Basyaib, F. 2004. "Teori Pembuatan Keputusan". Gramedia Widiasarana Indonesia. PT Grasindo. Jakarta.

[6] Cannon, P. Perreault dan Charthy.2008. "Pemasaran Dasar Basic Marketing Pendekatan Manajerial Global". Edisi 16. Salemba Empat. Jakarta.

[7] Eriyanto. 2007. "Teknik Sampling Analisis Opini Publik". PT LkiS Pelangi Aksara. Yogyakarta.

[8] Ibnularoby,. 2013. "Persepsi Konsumen Terhadap Marketing Mix-7P pada Perusahaan PO.SAN Bengkulu".

[9] Lvy, Jonathan., 2008. "A New Higher Education Marketing Mix The 7Ps For MBA Marketing”. City University, Birmingham. UK.

[10] Nasution, Rozaini. 2003."Teknik Sampling”. Tugas Akhir Fakultas Kesehatan Masyarakat Universitas Sumatera Utara (Digized by USU Digital Library). Medan.

[11] Nofriansyah, D. 2014. “Konsep Data Mining Vs Sistem Pendukung Keputusan”. Deepublish. CV Budi Utama. Yogyakarta.

[12] Pardede, P, P., 2011. "Manajemen Strategi dan Kebijakan Perusahaan". Terbitan Ketujuh. Halaman 23-25, 33-34, Terbitan Mitra Wacana Media.

[13] Rendy,. Defie. "Analisa Pengaruh Activity Based Costing Terhadap Keunggulan Bersaing Dan Kinerja Organisasi". Jurnal Business Accounting Review Vol. 1, No. 2, Jurusan Akuntansi Bisnis, Universitas Kristen Petra, Surabaya.

[14] Santoso, S. 2017. "Statistik Multivariat Dengan SPSS”. PT Elex Media Komputindo. Jakarta. 
[15] Suharyanto, H. 2003. "Langkah Pertama Jadi Pengusaha UMKM". Jubilee Enterprise.

[16] Tjiptono, F, Chandra, G,Dan Adriana, D,. 2008. "Strategi Pemasaran". Edisi Pertama, Penerbit CV. Andi Offset, Yogyakarta.

[17] Umar. H. 2003. "Metode Riset Bisnis Dilengkapi". Gramedia Pustaka Utama. Jakarta.

[18] Wicaksono, Y. 2006. "Ssbbti: Apl. Exel Menganalisis Data $+c d$ ". PT Elex Media Komputindo. Jakarta.

[19] Zulfikar. 2016. "Pengantar Pasar Modal dengan Pendekatan Statistika". Grup Penerbitan CV Budi Utama. Yogyakarta. 